\title{
CHORIOID PLEXUS IN SHEEP AND GOAT: A SCANNING ELECTRON MICROSCOPY STUDY OF THE FOETUSES
}

\author{
V. RAJTOVÁ \\ Department of Anatomy and Histology, University of Veterinary Medicine, Košice, Slovak Republic
}

Received August 1, 1997

Accepted January 15, 1998

\begin{abstract}
Rajtová V.: Chorioid plexus in Sheep and Goat: a Scanning Electron Microscopy Study of the Foetuses. Acta vet. Brno 1997, 66: 199-202.

The surface of the chorioid plexus in sheep and goat foetuses from day 62 to 145 of their foetal development was studied using the scanning electron microscope. No changes were found in the structure of the chorioid plexus surface in sheep and goat foetuses in relation to their age or gender. The chorioid plexus surface was covered predominantly with microvilli, sporadic short cilia or their clusters, which often occurred in the fourth cerebral ventricle: Secretory protrusions in the lateral and third cerebral ventricle were rare, but the occurrence of epiplexus (supraependymal) cells at these sites was abundant. There were abundant secretory protrusions on the surface of the fourth cerebral ventricle unlike the other parts of the ventricular system of the brain. However, epiplexus cells did not occur at this site.
\end{abstract}

Central nervous system, plexus chorioideus, cerebral ventricles, microvilli, cilia, secretory protrusions

The chorioid plexus, which takes part in the formation and resorption of the cerebrospinal fluid, is also a part of the cerebral ventricles. For the most part, it develops independently. The histogenesis and developmental stages of the human chorioid plexus in the light microscope were described by Shuangshoti and Netzky (1966), Duckett (1971), O'Rahilly and Müller (1990). Scott et al. (1974), Otani and Takana (1988) dealt with the structure of the foetal human chorioid plexus, including its surface structures in the scanning electron microscope. Chamberlain and Maglio (1972), Chamberlain (1973) studied the chorioid plexus and its surface structures in the cerebral ventricular system of 13-21 day-old rat foetuses in the scanning electron microscope. The surface structure of the chorioid plexus cells in mice from days 11 to 18 of their prenatal life, in newborn mice, and in the postnatal period (to day 90) was described by Sturrock (1979) and Zaki (1981). The development of vascularization and the chorioid plexus structure on foetal and postnatal material studied in the transmission electron microscope was presented by Tennyson and Pappas (1960, 1964). Jones (1980) briefly remarked on the chorioid plexus development in the rat, and - among farm animals - in the pig. In other farm animals, there are no data either on the postnatal or on the foetal chorioid plexus, which would serve for differentiation from pathological malformations.

The aim of this paper is to describe the structure of the exterior surface of the chorioid plexus in sheep and goat foetuses using the scanning electron microscope.

\section{Materials and Methods}

Sixteen goat and 8 sheep foetuses with crown-rump-length (C-R-L) of 120 to $470 \mathrm{~mm}$. corresponding to days $62-145$ in their development, were used. They were obtained by the caesarian section. Immediately after their removal from the uterus, their heads were perfused through a. carotis communis or aorta with a phosphate buffer solution $0.2 \mathrm{~mol} / \mathrm{l}$, then with Karnovsky solution. The chorioid plexus specimens from the lateral, third 
and fourth cerebral ventricle were postfixed in $3 \%$ of glutaraldehyde, then processed by Murakami et al. (1977), dried by the critical point method, coated with gold and studied in the scanning electron microscope Tesla BS 340.

Besides the above-mentioned specimens, 7 goat foetuses and 8 sheep foetuses obtained at random, were used. These were fixed with formaldehyde or Bouin's solution, and serial paraffin sections were stained with hematoxylin-eosin. These sections were used to check the surface structures and for orientation in the ventricular system.

\section{Results}

In all the examined foetuses of sheep and goat, independently of their age or gender, the surface morphology of the chorioid plexus was the same in the scanning electron microscope between days 62 and 145 of development. Only small differences were recorded in the outer configuration of the chorioid plexus: in the ventriculus lateralis it formed low, not always apparent folds (Plate I., Fig. 1) alternating with slightly convex surfaces of the apical membranes of ependymal cells, while in the third and fourth cerebral ventricle, the chorioid plexus formed characteristic aggregations of folds upon which the surface membranes of ependymal cells were convex (Plate I., Fig. 2.).

The ventricular surface of the chorioid plexus cells in all the examined foetuses was covered with sporadic or clustered short cilia. On the larger part of the apical membranes, there were dense or sparse fibrous microvilli.

In the area of ventriculus lateralis on the chorioid plexus surface between microvilli, there were tiny, spherical to elongated protrusions, which were scattered or arranged in small groups (Fig. 1.). The frequent occurrence of supraependymal (epiplexus) cells with elongated or irregular bodies were characteristic of the chorioid plexus ventriculi lateralis of the examined foetuses of both small ruminants (Plate II., Figs. 3, 4). From them 2-3 or more processes projected. Some of them were thin, the others formed wide "ruffled membranes". The epiplexus cells apparently came through "slits" in the chorioid plexus (Fig. 4). Their cell surface of the body and processes was smooth.

In the area of the third cerebral ventricle, the chorioid plexus (CHP) surface was covered predominantly with dense, fibrous microvilli. Small spherical protrusions in this part of the chorioid plexus occur only sporadically; on the other hand, however, in various sites on the free surface or in its depressions there are sporadic or grouped epiplexus cells (Plate III., Fig. 5A,B). They have two or more short processes which are completely changed to "ruffled membranes". The surface of the body and the ruffled membranes was smooth.

The plexus chorioideus ventriculi quarti was covered with dense microvilli and short cilia, which were scattered or arranged in tufts. These cilia were most abundant in the area of the fourth cerebral ventricle. In this part of the ventricular system, the chorioid plexus surface was covered with abundant, suspended almost overhanging spherical protrusions (Platze IV., Figs. 6, 7). At some sites, there is a tendency for the protrusion to fuse into so-called "lakes" of various sizes. In one case, epiplexus cells were absent from the chorioid plexus surface of the fourth cerebral ventricle.

\section{Discussion}

The surface of the chorioid plexus in human foetuses ( $\mathrm{S} \mathrm{cott}$ et al.; 1974, O t a $\mathrm{n} \mathrm{i}$ and Tanaka 1988) or rat (Chamberlain and Maglio 1972; Chamberlain 1973) is covered with cilia, microvilli and small spherical protrusions already in the early prenatal period. A similar finding could be seen also in the foetuses of both the small ruminants 
studied, with the difference that the youngest foetuses were 62 days old. In human ( $\mathrm{S} \mathrm{c}$ o $\mathrm{t} \mathrm{t}$ et al. 1974) as well as in rat foetuses ( $\mathrm{C} \mathrm{h} \mathrm{a} \mathrm{m} \mathrm{b} \mathrm{e} \mathrm{r} \mathrm{l} \mathrm{a} \mathrm{in} \mathrm{1973)} \mathrm{the} \mathrm{presence} \mathrm{of} \mathrm{epiplexus}$ cells on the surface of the chorioid plexus was not reported, while in mice these cells were described (Sturrock 1978, 1979; Zaki 1981).

Epiplexus (supraependymal) cells occurred in greater or lesser numbers in goat and sheep foetuses between days 62 and 145 in their development, but their presence did not depend on the species, age or gender of foetuses. It follows from our findings that epiplexus cells were bound with the number of spherical (secretory) protrusions as in the case of the ependymal lining of the ventricular system of the brain of the prenatal material from goats and sheep (Rajtová, Kačmarik - in press), and also in the case of adult small ruminants (Rajtová $1988,1990)$. The highest number of secretory protrusions was recorded in the fourth ventricle where, however, epiplexus cells were missing. Secretory activity of the chorioid plexus ventriculi lateralis was minimal, and only sporadic spherical protrusions occurred. In both cerebral ventricles, there were individual epiplexus cells or clusters of them.

If the secretory activity of the foetal chorioid plexus is compared with the foetal ependyma of goats and sheep (Rajtová, Kačmarik - in press), it may be concluded that it is substantially higher in the ependyma, which, in the prenatal period, probably takes part in the formation of the cerebrospinal fluid to a greater extent than the chorioid plexus. Based upon the present study of the ependyma in adult sheep and goat under the physiological and experimental conditions (Rajtová 1990, 1992, 1993) as well as the study of the chorioid plexus surface in small ruminants, it is not known, why supraependymal or epiplexus cells were missing at the sites of the abundant occurrence of secretory protrusions.

No differences have been found in the structure of the foetal choroid plexus between sheep and goats, while in the structure of the foetal ependyma these differences are pronounced (Rajtová, Kačmarik - in press). It is interesting that these differences from the foetal period persist to maturity (Rajtová 1988, 1990, 1995).

\section{Plexus chorioideus oviec a kôz: SEM štúdie fétusov}

Povrch plexus chorioideus ovčích a kozích plodov medzi 62. a 145. dñom ich vývoja sme sledovali pomocou SEM. V štruktúre povrchu plexus chorioideus sme nenašli zmeny ani u plodov oviec a kôz vo vztahu $\mathrm{k}$ veku alebo pohlaviu. Povrch plexus chorioideus bol pokrytý prevážne mikroklkmi, sporadickými cíliami alebo ich zväzkami, ktoré sa často vyskytovali vo štvrtej komore mozgovej. Sekrečné protrúzie $\mathrm{v}$ laterálnej a tretej mozgovej komore boli zriedkavé, ale výskyt epiplexových (supraependymálnych) buniek na týchto miestach bol častý. Početné sekrečné protrúzie boli na povrchu štvrtej komory mozgovej na rozdiel od iných častí ventrikulárneho systému mozgu. Avšak epiplexové bunky sa na tomto mieste nevyskytovali.

\section{References}

CHAMBERLAIN, J. G. 1973 :Analysis of developing ependymal and chorioidal surfaces in rat brains using scanning electron microscope. Develop. Biol. 31: 22-30

CHAMBERLAIN, J. G., MAGLIO, M. 1972: Scanning electron microscopy of prenatal rat brain during normal and abnormal development. Act. Rec.: 172: 287 (Abst.)

DUCKETT. S. 1971: The chorioid plexus of the lateral ventricles during early human fetal life. Anat. Anz. 129: $77-83$

JONES. H. C. 1980: Intracellular pores between the ependymal cells lining the roof of the fourth cerebral ventricle in mammalian fetuses. Z. Kinderchir. 31: 309-316

MURAKAMI, T., YAMAMOTO, K.. ITOSHIMA, T. 1977: Modified tanin-osmium conductive staining method for non-coated SEM specimens and application to microsection SEM of spleen. Arch. histol. Jap. 40: 35-40

O` RAHILLY, R., MÜLLER, O. 1990: Ventricular system and chorioid plexuses of the human brain during the embryonic period proper. Am. J. Anat. 189: 285-302 
OTANI, H., TANAKA, O. 1988: Development of the chorioid plexus anlage and supraependymal structures in the fourth ventricular roof plate of human embryos: scanning electron microscopic observations. Am. J. Anat. 181: 53-66

RAJTOVÁ, V. 1980: Ependym beim Schaf. 5. Teil. Ependymauskleidung der Gehirnkammern im Rasterelektronmikroskop. J. Hirnforsch. 29: 221-235

RAJTOVÁ. V. 1990: Ependyma of the goat. I. The third cerebral ventricle: Scanning electron microscopy study. J. Hirnforsch. 31: 298-303

RAJTOVÁ, V. 1992: Ependyma of the goat. Part IV. Ependymal lining of the median eminence under physiological and experimental conditions. Anat. Histol. Embryol. 21: 68-75

RAJTOVÁ, V. 1993: Recessus infundibuli of the third cerebral ventricle in goats under physiological and experimental conditions. Int. J. Anim. Sci. 8: 27-31

RAJTOVÁ, V. 1995: Morphology of supraependymal cells and their occurence in the cerebral ventricles of sheep and goat. A scanning electron microscopy study. Acta vet. Brno 64: 17-21

RAJTOVÁ. V. KAĆMARIK J.: Foetal ependyma in sheep and goat. A scanning electron microscopy study. Anat. Histol. Embr. (in press)

SCOTT, D. E., Van DYKE, D., PAULL, W. K., KOZLOWSKI, G. P. 1974: Ultrastructural analysis of the human cerebral ventricular system. Cell Tissue Res. 150: 389-397

SHUANGSHOTI, S., NETSKY, M. G. 1966: Histogenesis of plexus chorioideus in man. Am. J. Anat. 118: $283-$ 316

STURROCK, R. R. 1978: A developmental study of epiplexus cells and supraependymal cells and their possible relationship to microglia. Neuropathol. Appl. Neurobiol. 4: 307-322

STURROCK, R. R. 1979: A morphological study of the mouse chorioid plexus. J. Anat. 129: 777-793

TENNYSON, V. M. 1960: An electron microscopic study of newborn plexus chorioideus from normal and hydrocephalic rabbits. Anat. Res. 136: 290 (Abstr.)

TENNYSON, V. M., PAPPAS, G. P. 1964: Fine structure of the developing telencephalic and myelencephalic chorioid plexus in the rabbit. J. comp. Neurol. 123: $379-412$

ZAKI, W. 1981: Ultrastructure of the choriod plexus and its development in the mouse. Z. mikr.-anat. Forsch. 95: 919-935

Address for correspondence:

Prof. MVDr. Viera Rajtová, DrSc.

Department of Anatomy

University of Veterinary Medicine

Komenského 73

04181 Košice

Slovak Republic

Phone: 421956229924

Fax: $\quad 421956323666$

E-mail: anatomia@vsvnov.uvm.sk 
Plate I.

Rajtová V.: Chorioid plexus... pp. 199-202

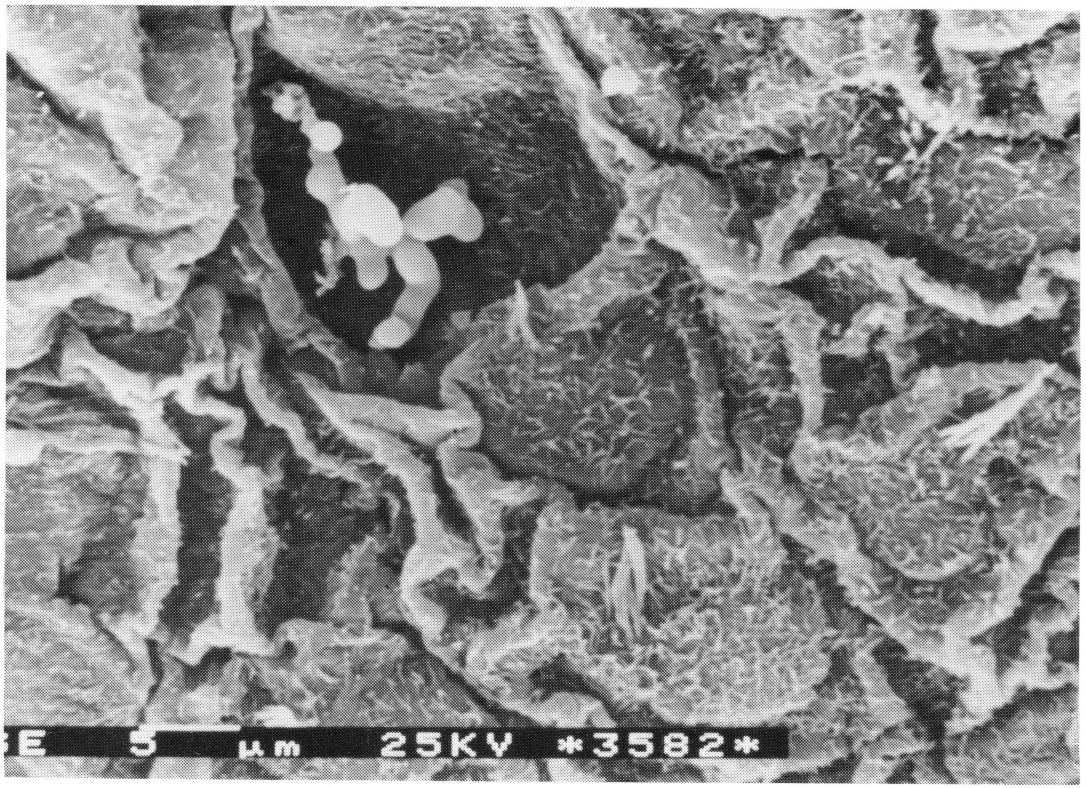

Fig. 1.: The surface of the plexus chorioideus ventriculi lateralis covered with microvilli and sporadic short cilia and secretory protrusions. Male goat foetus on the 62 nd day of prenatal life.

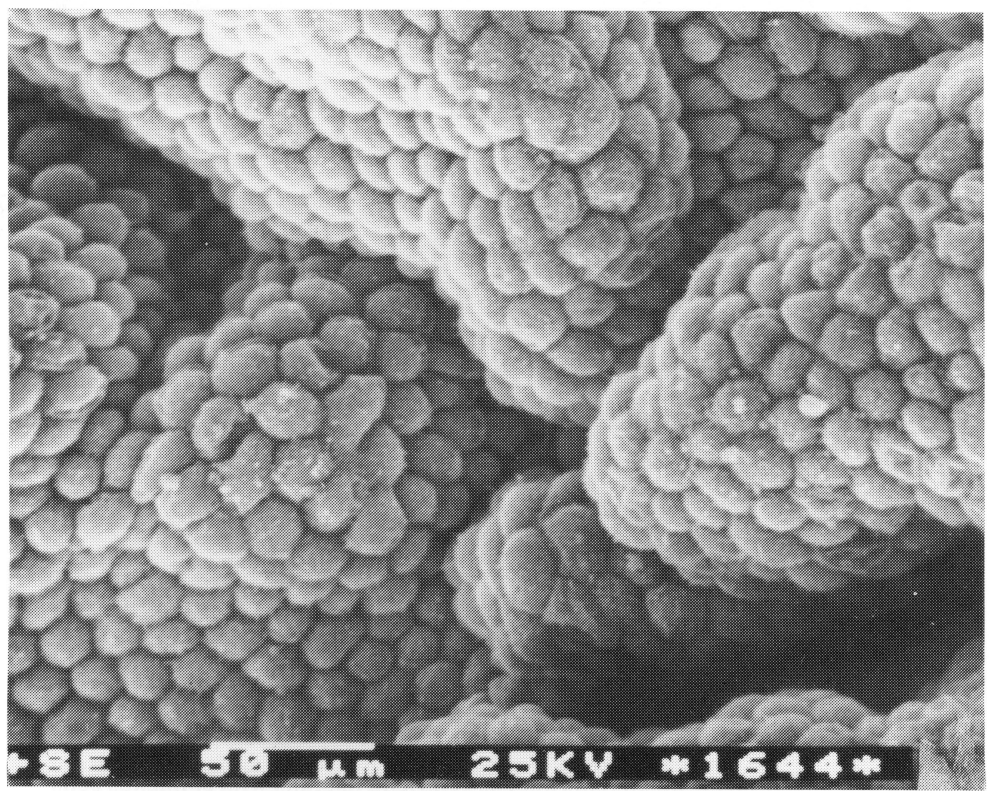

Fig. 2.: Some folds of the plexus chorioideus ventriculi tertii with pronounced convex ependymal cells. Female goat foetus on the 79th day of prenatal life. 


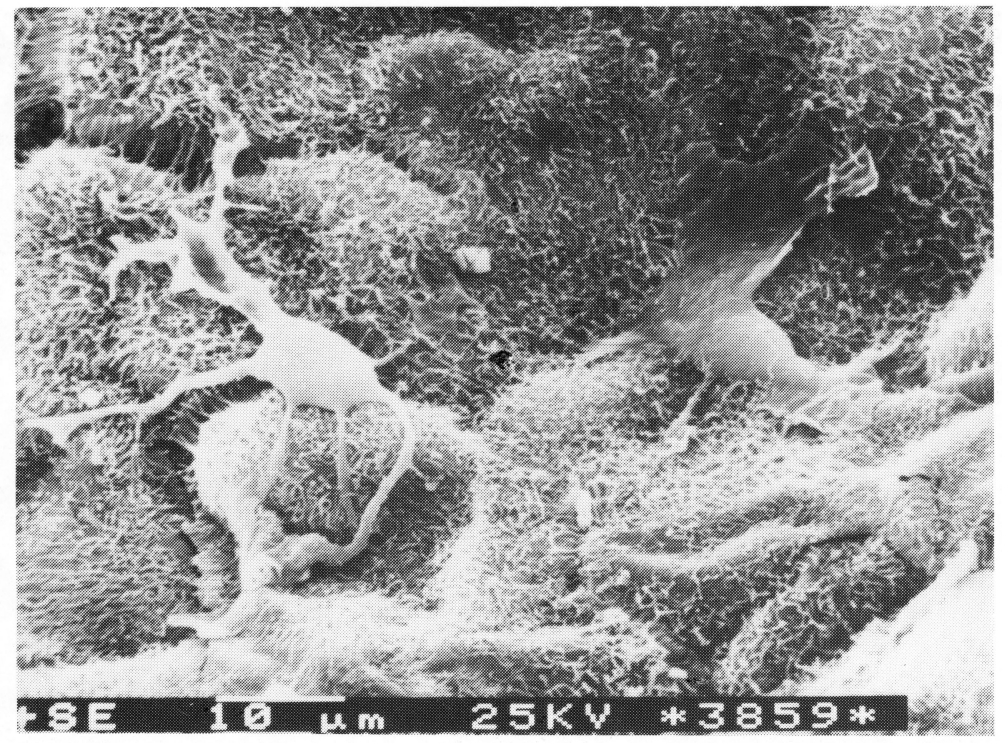

Fig. 3.: Details from the surface of the plexus chorioideus ventriculi lateralis with epiplexus cells. Male goat foetus on the 92 nd day of prenatal life.

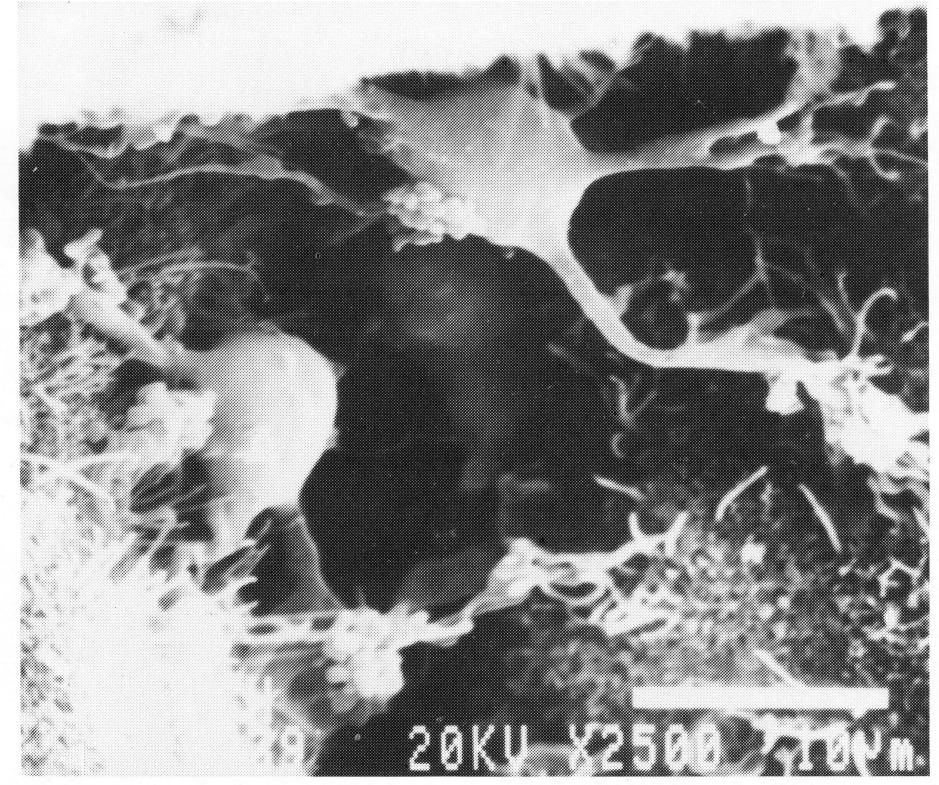

Fig. 4.: Details from the plexus chorioideus ventriculi lateralis with epiplexus cells coming through ,lacunas“ between folds. Male goat foetus on the 92nd day of prenatal life. 
Plate III.

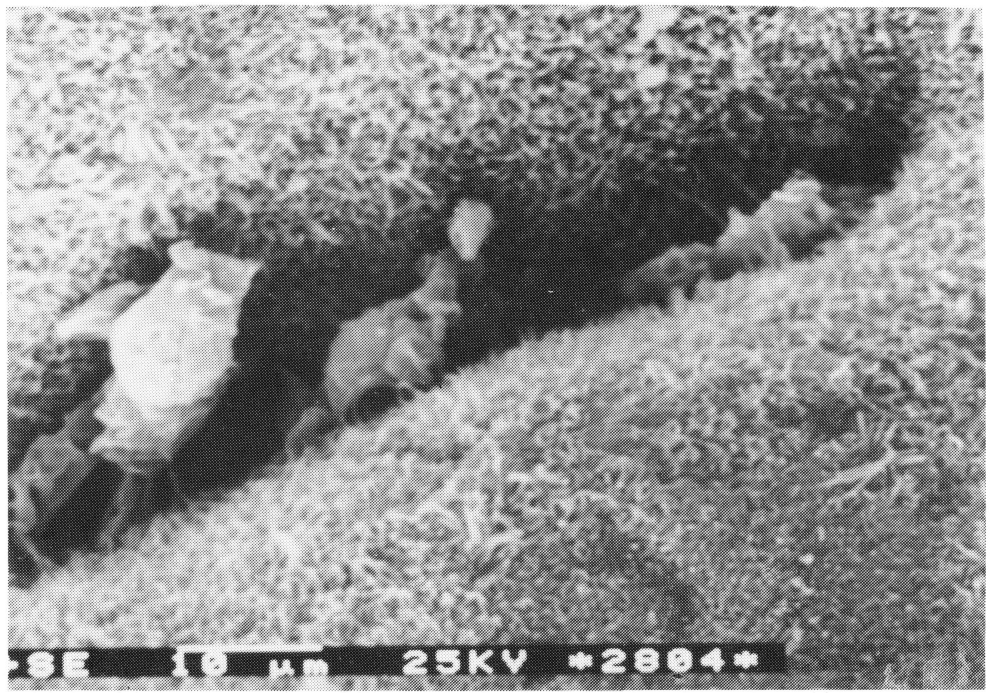

Figs 5A, B.: Details from the plexus chorioideus ventriculi tertii with epiplexus cells, which protrude onto the surface through deep ,lacunas“. Fig. 5A. Goat foetus, on day 71 of development (male).

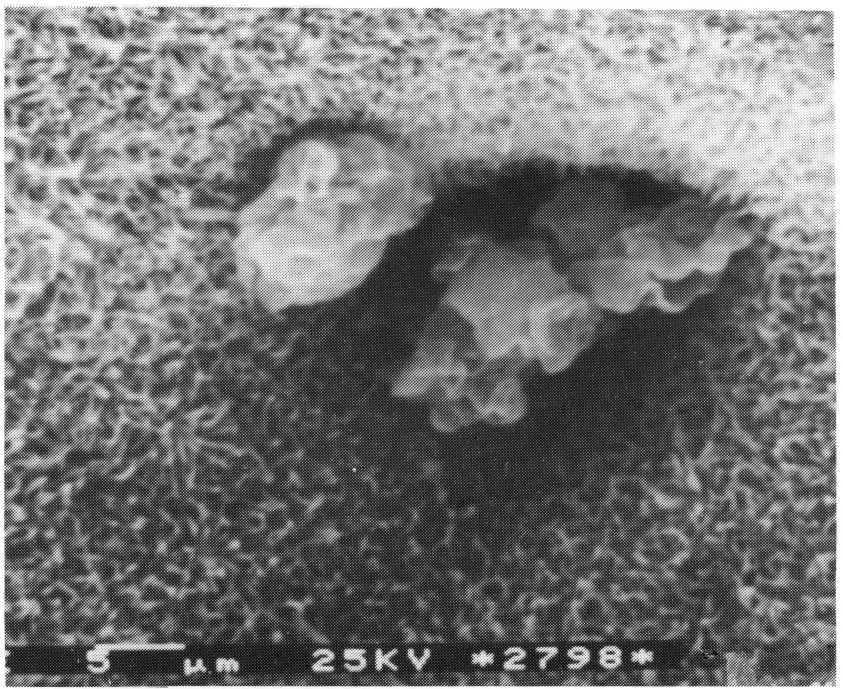

Fig. 5B. Sheep foetus on day 85 of development (female). 


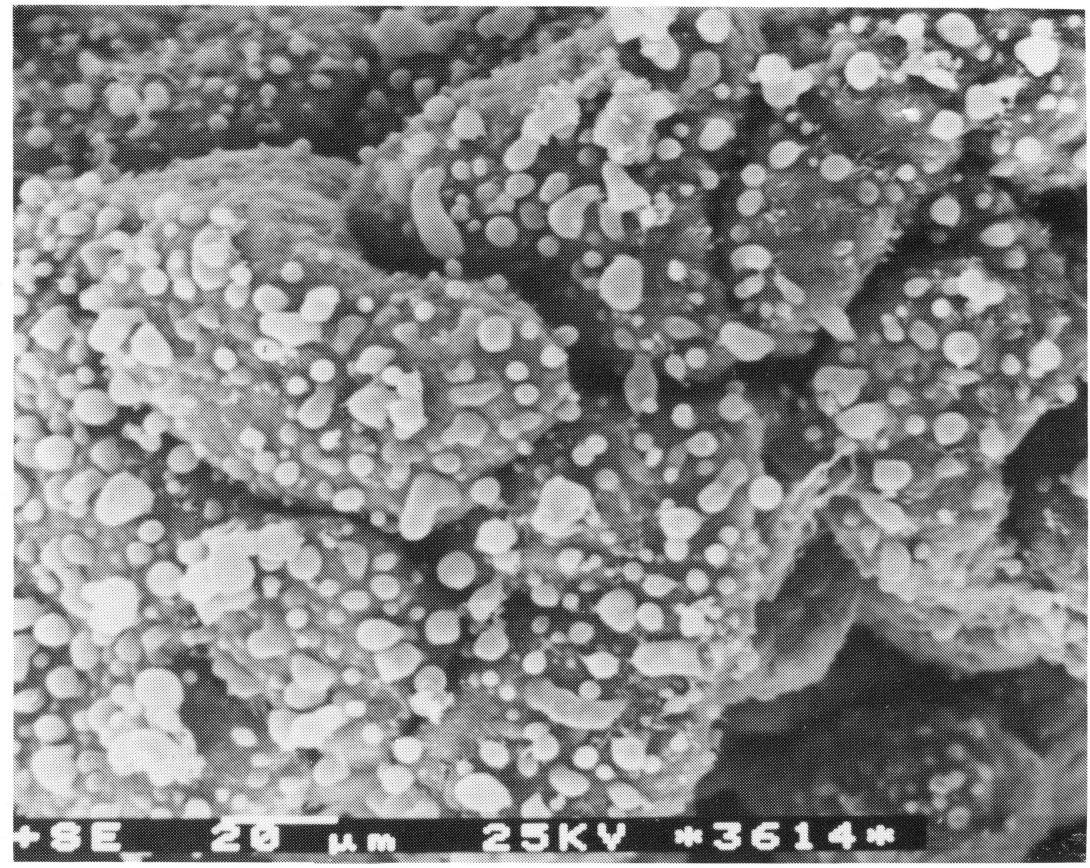

Figs 6 and 7.: The pl. chorioideus ventriculi quarti with abundant, round to overhanging, secretory protrusions. On the surface, see microvilli and sparse short cilia. Male goat foetus, 92 nd day of prenatal life.

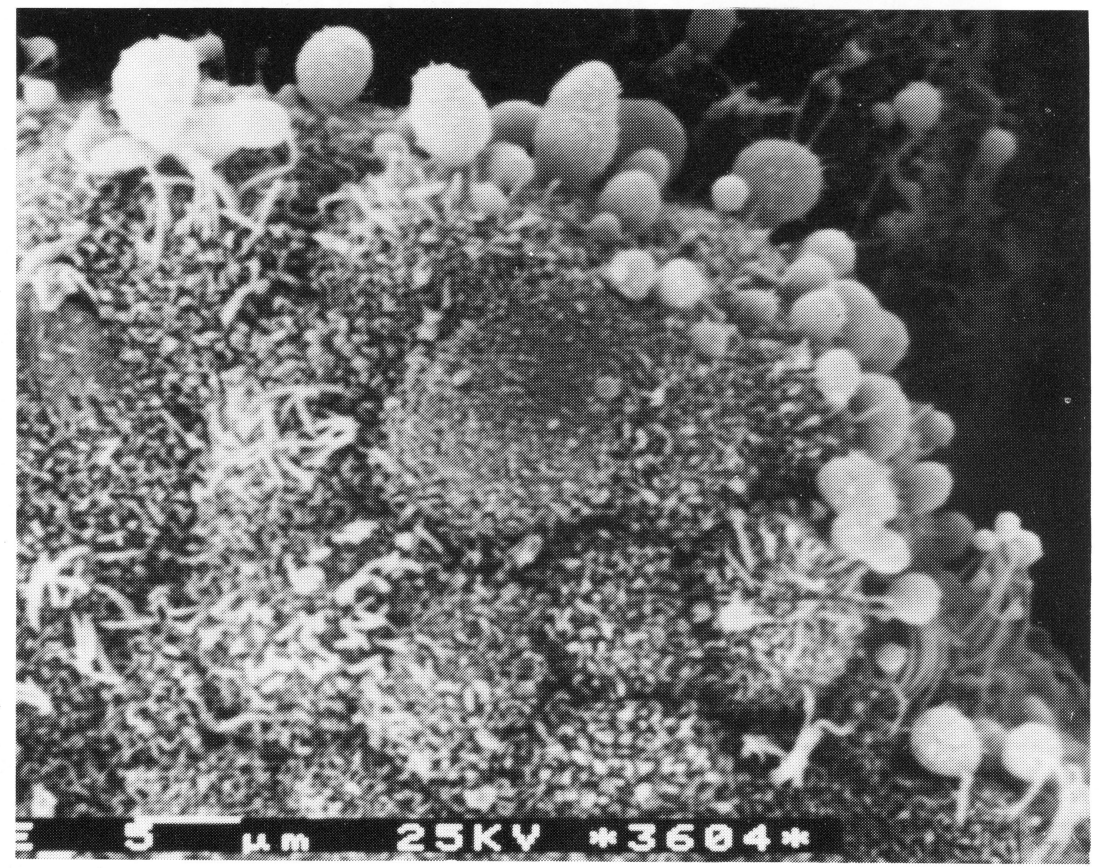

